\title{
The Complex Interplay between Immunonutrition, Mast Cells, and Histamine Signaling in COVID-19
}

\author{
Sotirios Kakavas ${ }^{1}$, Dimitrios Karayiannis ${ }^{2, *(\mathbb{D})}$ and Zafeiria Mastora ${ }^{3}$ \\ 1 Critical Care Department, "Sotiria" General Hospital of Chest Diseases, 152 Mesogeion Avenue, \\ 11527 Athens, Greece; sotikaka@yahoo.com \\ 2 Department of Clinical Nutrition, Evangelismos General Hospital of Athens, Ypsilantou 45-47, \\ 10676 Athens, Greece \\ 3 First Department of Critical Care Medicine and Pulmonary Services, Evangelismos General Hospital, \\ National and Kapodistrian University of Athens, 11527 Athens, Greece; zafimast@yahoo.gr \\ * Correspondence: dkarag@hua.gr; Tel.: +30-213-2045035; Fax: +30-213-2041385
}

Citation: Kakavas, S.; Karayiannis, D.; Mastora, Z. The Complex Interplay between Immunonutrition, Mast Cells, and Histamine Signaling in COVID-19. Nutrients 2021, 13, 3458 https://doi.org/10.3390/nu13103458

Academic Editor: Arved Weimann

Received: 3 September 2021

Accepted: 27 September 2021

Published: 29 September 2021

Publisher's Note: MDPI stays neutral with regard to jurisdictional claims in published maps and institutional affiliations.

Copyright: () 2021 by the authors. Licensee MDPI, Basel, Switzerland. This article is an open access article distributed under the terms and conditions of the Creative Commons Attribution (CC BY) license (https:// creativecommons.org/licenses/by/ $4.0 /)$.

\begin{abstract}
There is an ongoing need for new therapeutic modalities against SARS-CoV-2 infection. Mast cell histamine has been implicated in the pathophysiology of COVID-19 as a regulator of proinflammatory, fibrotic, and thrombogenic processes. Consequently, mast cell histamine and its receptors represent promising pharmacological targets. At the same time, nutritional modulation of immune system function has been proposed and is being investigated for the prevention of COVID19 or as an adjunctive strategy combined with conventional therapy. Several studies indicate that several immunonutrients can regulate mast cell activity to reduce the de novo synthesis and/or release of histamine and other mediators that are considered to mediate, at least in part, the complex pathophysiology present in COVID-19. This review summarizes the effects on mast cell histamine of common immunonutrients that have been investigated for use in COVID-19.
\end{abstract}

Keywords: immunonutrition; COVID-19; histamine

\section{Introduction}

Severe acute respiratory syndrome coronavirus 2 (SARS-CoV-2) is an enveloped singlestranded positive-sense ribonucleic acid (RNA) virus that was first detected in China and has caused an ongoing global pandemic [1]. SARS-CoV-2 comprises four identified structural proteins, namely, spike (S), membrane (M), envelope (E), and nucleocapsid (N) [2]. In general, the virus infects by binding its $S$ protein to the host's angiotensin-converting enzyme 2 (ACE2) receptors, then entering by endocytosis into airway epithelium cells, lung macrophages, alveolar epithelial cells, and vascular endothelial cells [3,4]. Patients may remain asymptomatic or develop symptoms of varying severity [5,6]. In the resulting coronavirus disease 2019 (COVID-19), activation of the innate immunity, specific antibodies, and activated $\mathrm{T}$ cells represent basic defensive factors, while in more severe cases, lung injury progresses and leads to respiratory failure [5,7]. Severe lung injury in SARS-CoV-2 patients is considered the result of immune hyperreaction that involves both innate and adaptive immune responses [6,8]. Briefly, coronavirus infection activates antigen-presenting cells, such as macrophages, that display viral antigens to $\mathrm{T}$ and $\mathrm{B}$ cells resulting in antibody production and increased cytokine secretion in the form of a cytokine storm. Other immune cells are also implicated, including mast cells, which are important coordinators for both innate and adaptive immunity [9]. Endothelial injury and microthromboses ensue in the lungs and other organs of COVID-19 patients $[10,11]$. Patients may require mechanical ventilation and develop multiple organ failure $[5,6]$.

Histamine is an endogenous biogenic amine that functions as a neurotransmitter and an immunoregulatory factor. In the immune system, histamine is mainly stored in cytoplasmic granules of mast cells and basophils and is released upon triggering along 
with other mediators such as serotonin, proteases (e.g., tryptase and chymase), heparin, a variety of cytokines, and angiogenic factors [12]. Histamine release can be activated by numerous innate signals or exogenous triggers [13] including allergens, toxins, and viruses [14]. The high-affinity immunoglobulin (Ig)E receptor, FcepsilonRI (FceRI), is the primary receptor in mast cells that mediates IgE-dependent (allergic) reactions [12]. Yet, it is apparent that non-IgE-mediated mechanisms of mast cell activation also exist [13]. Histamine exerts its biological actions through four types of $\mathrm{G}$ protein-coupled histamine receptors (i.e., $\mathrm{H} 1$ receptor, $\mathrm{H} 2$ receptor, $\mathrm{H} 3$ receptor, and $\mathrm{H} 4$ receptor) [15]. It also activates acute immune-mediated reactions and enhances vascular smooth muscle contraction and the migration of other immune cells, antibodies, and mediators to the site of insult [7]. The release of histamine by perivascular mast cells may also affect adjacent lymphatic vessel function inducing immune cell trafficking through its lumen, which potentially contribute to acute inflammatory stimulus [16]. In the lungs, this may cause bronchoconstriction, increased mucus production, increased vasopermeability with edema, microthrombosis, and infiltration by leukocytes, predominantly neutrophils [17]. Histamine can regulate the balance between Th1 and Th2 effector cells [18]. During histamine-mediated lung inflammation, secretion of Th2 cytokines is enhanced, while production of Th1 cytokines is suppressed [19]. This response may increase susceptibility to viral and bacterial infections of the respiratory tract [5]. In addition, viral remnants may prolong and exaggerate the inflammatory process, causing a histamine-induced release of more pro-inflammatory Th2 cytokines through an IgE-mediated positive feedback vicious cycle [5].

A growing body of evidence has implicated histamine and mast cells in COVID19 [20-22]. In animal models of COVID-19, mast cells detected in the lungs were chymase positive [23]. Mast cells are shown to express histamine receptors by themselves which, in an autocrine fashion, can potentially ensue a feedback regulation further enhancing inflammatory response [16,24]. The SARS-CoV-2 infection has been shown to activate mast cells leading to histamine release that increases IL-1 levels, causing hyper-inflammation and cytokine storm [25]. Mast cell degranulation has been reported in alveolar septa of deceased patients with COVID-19 and in SARS-CoV-2-infected mice and non-human primates [23,26]. Furthermore, this mast cell activation was associated with interstitial edema and immunothrombosis [27], while the levels of the mast cell-specific protease, chymase, correlated significantly with disease severity [23]. Moreover, studies have reported that $\mathrm{H} 1$ as well as $\mathrm{H} 2$ receptor antagonists, such as famotidine, are associated with a reduced risk of infection and deterioration leading to intubation or death from COVID-19 [28,29]. These agents are considered to improve pulmonary symptoms of SARS-CoV-2 infection by blocking the histamine-mediated cytokine storm [30]. Nevertheless, these observational findings need further validation by the ongoing randomized clinical trials.

Given that limited therapeutic modalities are available for the treatment of COVID-19, nutritional modulation of the immune system function has been proposed and is being investigated [31-34]. It is widely accepted that normal nutritional status is vital for immune homeostasis [35], while a number of recently published key studies suggest promising effects of immunonutrition on acute respiratory infections [36,37]. Briefly, immunonutrition can be defined as modulation of either the activity of the immune system or modulation of the consequences of activation of the immune system by nutrients or specific food items fed in amounts above those normally encountered in the diet [38]. Until now, specific immunonutrients have been proposed as effective for the prevention of COVID-19 or as an adjunctive strategy combined with conventional therapy [39]. At the same time, these nutraceuticals have been reported to modulate mast cell activation and histamine release with similar potency to pharmacological interventions $[40,41]$. This review summarizes the effects on mast cell and histamine signaling of common immunonutrients that have been investigated for use in COVID-19. 


\section{Vitamins}

\subsection{Vitamin D}

Vitamin D has been linked to the susceptibility to SARS-CoV-2 infection and the prognosis of COVID-19 based on a series of data [32]. There is evidence that vitamin $\mathrm{D}$ inhibits the entry and replication of SARS-CoV-2 and suppresses the levels of proinflammatory cytokines while enhancing the production of anti-inflammatory cytokines and antimicrobial peptides [42]. According to epidemiological observations, vitamin D deficiency has been associated with a higher risk, severity, and mortality rate of COVID$19[43,44]$. However, conflicting results have been reported concerning the effects of vitamin D supplementation in outpatients and hospitalized patients after COVID-19 diagnosis in terms of disease severity, hospital length of stay, ICU admission, or mortality rate [45-48]. Although, no official guidelines exist, it has been proposed to aim for adequate serum $25(\mathrm{OH}) \mathrm{D}$ levels of at least $30 \mathrm{ng} / \mathrm{mL}(75 \mathrm{nmol} / \mathrm{L})$ during the pandemic [49]. Further results are pending ongoing clinical trials [50].

Vitamin D seems to preserve the stability of mast cells, possibly by maintaining the expression of vitamin D receptors. In a vitamin D-deficient environment, mast cell activation occurs automatically, even in the absence of specific triggering [51]. In addition, it has been shown that vitamin $\mathrm{D}$ inhibits histamine release from mast cell activation including IgE-mediated activation [52]. Likewise, decreased levels of serum histamine have been found after the antigenic challenging of sensitized mice previously receiving a vitamin D supplemented diet [51]. According to this study, vitamin D receptor binding inhibits mast cell activation by blocking the non-receptor tyrosine kinase Lyn. Lyn is recruited immediately during mast cell activation following the crosslinking of FceRI-IgE complexes by multivalent antigens or exposure to the bacterial lipopolysaccharide $[53,54]$. Furthermore, the phosphorylation of the Syk tyrosine kinase was also suppressed by vitamin D receptor binding to the $\beta$ chain of FceRI. Syk activation can be triggered by Lyn and is involved in mast cell degranulation [55]. Recent data also indicate a positive effect of vitamin D supplementation on functional humoral immunity levels as determined by IgG levels [56].

\subsection{Vitamin $E$}

Vitamin $\mathrm{E}$ is a lipid-soluble vitamin with antioxidant and immunomodulatory properties. In addition to scavenging free radicals, vitamin $\mathrm{E}$ can affect immune function by modulating signal transduction and gene expression [57-59]. In this way, vitamin $E$ has been found to reduce susceptibility to respiratory infections as well as allergy-related diseases such as asthma [59]. Vitamin E has been implicated in the treatment of SARS-CoV-2 infection in an effort to minimize oxidative damage in these patients [33]. However, limited evidence exists on the use of vitamin $\mathrm{E}$ as an adjuvant agent for the treatment of COVID-19 patients, and information resulting from clinical trials is wanted [60].

Vitamin $\mathrm{E}$ has been shown to have an inhibitory effect on the proliferation, secretion, and survival of mast cells [61]. This effect originates from the modulation of protein kinase C, protein phosphatase $2 \mathrm{~A}$, and protein kinase B in mast cells. Furthermore, in vitro studies in various mast cell lines have shown that vitamin $\mathrm{E}$ affects mast cell activation, resulting in a decreased release of proinflammatory mediators including histamine $[62,63]$. The effects of vitamin $\mathrm{E}$ on mast cell function could be related with the antioxidative properties of the vitamin [61]. Interestingly, oxidative stress and mast cells interact and participate in acute lung injury. Reactive oxygen species generation promotes pulmonary mast cell degranulation which, in turn, can increase oxidative stress and inflammation during acute lung injury [64].

\subsection{Vitamin C}

Vitamin C or ascorbic acid is a water-soluble antioxidant vitamin that possesses antiinflammatory and immunomodulatory properties [5]. Although the value of vitamin $C$ has not yet been demonstrated in COVID-19, it has gained interest in this context because of its 
antiviral action [65] and beneficial effects in oxidative damage and inflammation [66]. Vitamin $C$ has previously been implicated in sepsis and ARDS, both of which represent major complications of COVID-19 [67]. Although low levels of vitamin C have been reported in sepsis, conflicting results have been produced by studies evaluating vitamin $C$ supplementation in septic shock and ARDS [68,69]. At present, we are awaiting the results of several ongoing trials evaluating the value of oral or intravenous vitamin $C$ supplementation in the treatment of COVID-19. A daily oral dosage of 1-2 $\mathrm{g} /$ day of vitamin $\mathrm{C}$ has been proposed as beneficial for the prevention or treatment of COVID-19, while higher doses of intravenous vitamin C, up to $24 \mathrm{gm} /$ day, are being evaluated in critically ill patients with COVID-19. Proposed mechanisms for the ability of vitamin $C$ to benefit patients with COVID-19 point to the prevention of IL-6 increase in several (pro)inflammatory conditions and the inhibition of increases for a range of inflammatory cytokines [70,71].

Previous studies have shown that vitamin $C$ administration attenuates a robust immune response [72]. In fact, mast cell-mediated bronchial hypersensitivity caused by the common cold was inhibited by the administration of vitamin C [73]. These patients exhibited decreased bronchial hypersensitivity to histamine and bronchoconstriction after vitamin C administration [40]. Both preclinical [74-76] and clinical studies [76-78] have evaluated histamine blood levels after vitamin $C$ administration. In a recent study, $7.5 \mathrm{~g}$ of vitamin $C$ administered intravenously in 89 patients with allergies or upper respiratory infections caused a significant reduction in serum histamine [79]. Several mechanisms may be responsible for the inhibitory effect of vitamin C on histamine [79,80]; vitamin C may inhibit mast cell activation, increase histamine degradation by diamine oxidase or, alternatively, decrease histamine production by inhibiting histidine decarboxylase [81].

\section{Minerals}

\subsection{Zinc}

Zinc is the second most abundant essential trace element that plays important roles in the development, differentiation, and function of immune cells [33]. The perceived antiviral properties of zinc against upper respiratory tract viral infections derive from its participation in metallothioneins [82]. In this context, zinc may interfere with viral infection in many ways $[83,84]$. First, zinc may prevent viral attachment to nasopharyngeal mucous as well as fusion with the host's membrane and virus entry into cells. In particular, zinc has been shown to decrease the activity of the ACE2 receptor, which is essential for SARS-CoV-2 binding and the provocation of cytokine storm. Moreover, this trace element has been shown to hinder SARS-CoV-1 viral replication by inhibiting SARSCoV RNA polymerase [85]. Further antiviral effects of zinc include the impairment of viral protein translation and the blockade of viral particle release [86]. Zinc deficiency is common in COVID-19 patients and is associated with more complications and increased mortality [42]. In older adults, supplementation with $45 \mathrm{mg}$ elemental zinc per day has been shown to reduce the risk of infection [31]. In summary, it has been proposed that zinc supplementation may be beneficial in the prevention and treatment of SARS-CoV-2 infection and the associated inflammation [87-89]. At present, a series of clinical trials have been registered to test the efficacy of various regimens containing zinc against COVID-19.

Zinc deficiency has been demonstrated to affect the function of various types of immune cells including mast cells $[90,91]$. Zinc seems to be essential for mast cell activation. In an in vitro study, the release of histamine from human basophils and lung mast cells was inhibited from physiological concentrations of zinc [92]. A possible mechanism may include the blockade of $\mathrm{Ca} 2+$ influx induced by the IgE-mediated activation of mast cells [6]. On the other hand, a zinc chelator $(\mathrm{N}, \mathrm{N}, \mathrm{N}, \mathrm{N}$-tetrakis (2-pyridylmethyl) ethylenediamine) has been recently shown to contribute to the inhibition of histamine release from mast cells and this effect was reversed by zinc supplementation [93]. Zinc may regulate mast cell activation and function by modulating the PKC/NF- $\mathrm{KB}$ signaling pathway [90]. Various mechanisms have been suggested, but modulation of the NF-kB pathway could be the result of the inhibition of cyclic nucleotide phosphodiesterase, cross activation of protein kinase 
A, and inhibitory phosphorylation of protein kinase Raf-1 [94]. In addition, activation of NF-kB can also activate mast cells thereby releasing histamine secretion and an ensuing inflammatory response along with cytokine secretion [95].

\subsection{Selenium}

Selenium is a trace element that serves as an essential component of antioxidant enzymes. In this way, it exhibits a protective effect against respiratory infections including viral infections $[96,97](33,97,98)$. It has been suggested that selenium deficiency might be implicated in the evolution of SARS-CoV-2 [87]. Moreover, a number of studies have linked selenium with SARS-CoV2 infection and recovery rates [98-100]. Selenium may halt oxidative stress in patients with COVID-19 [33,39]. Interestingly, oxidative stress and mast cells show a bidirectional interaction. Intracellular reactive oxygen species production is the result of mast cells by various triggers [101], while mast cell degranulation can be controlled via the decrease in reactive oxygen species generation using antioxidants [62]. In accordance with this, an in vitro study showed that selenium can suppress the IgEmediated release of inflammatory mediators in a murine mast cell line, although histamine release only slightly decreased [102]. The regulation of redox-sensitive transcription factors is considered the responsible mechanism by which selenium affects mast cell histamine release [103]. Published data also highlight the important role of biological functions that occur via incorporation of selenium into selenoproteins in the form of selenocysteine amino acid residue. Selenocysteine (Sec-Cys) is involved in a variety of prostanoid metabolism processes and, therefore, have an impact on immunity [104].

\section{Omega-3 Fatty Acids}

Omega-3 fatty acids are polyunsaturated fatty acids (PUFAs) obtained mainly from two dietary sources: marine and plant oils. These fatty acids incorporate into the biphospholipid layer of the cell membrane and result in the reduced production of proinflammatory mediators [105]. To date, sparse evidence has implicated omega-3 fatty acids in the prevention and treatment of COVID-19 [106,107]. Nevertheless, it has been shown that the omega-3 PUFAs inactivate enveloped viruses like SARS-CoV2 and inhibit ACE2-mediated binding and cellular entry of SARS-CoV-2 [108]. Furthermore, beneficial reports of omega-3 PUFAs have been reported in patients with sepsis and sepsis-induced ARDS [109,110]. Several clinical trials assessing the effect of omega-3 PUFAs in COVID-19 management are currently registered (ZPD37). In a recent double-blind, randomized clinical trial, enteral supplementation with omega-3 PUFAs significantly improved respiratory and renal function indices as well as one-month survival rates in critically ill patients with COVID-19 [111].

Similar to other immune cells, fatty acids are incorporated into mast cell membranes and can differentially influence mast cell secretive properties $[62,112,113]$. Collectively, the actions of omega-3 PUFAs on mast cells are mainly inhibitory. A series of studies in animal models and in human cells has demonstrated the inhibitory effect of omega3 PUFAs on IgE-mediated activation of mast cells [26,114,115]. This effect is mediated by the inhibition of GATA transcription factors in mast cells and leads to suppressed Th2 cytokine expression [116]. As expected, this action of omega-3 PUFAs was tested to ameliorate the severity of mast cell-associated diseases $[117,118]$. In a canine atopic dermatitis model mast cell histamine release was reduced after treatment by $\gamma$-linolenic acid or $\alpha$-linolenic acid. On the other hand, linoleic acid or arachidonic acid enhanced histamine release $[113,119]$. However, in a model of stress-induced visceral hypersensitivity in maternally separated rats, neither mast cell degranulation nor hypersensitivity were affected by the administration of an omega-3 PUFA-enriched diet [120]. Clinical trials of the dietary omega-3 supplementation in asthma patients have reported beneficial effects on airway inflammation but inconsistent clinical benefits in terms of lung function indices [121]. Nonetheless, it should be noted that two of these studies reported clinical benefits of dietary 
supplementation with omega-3 PUFAs in asthma patients without an accompanying decrease in mast cell activation and histamine release [122,123].

\section{Phytochemicals}

\subsection{Flavonoids}

Flavonoids are a group of naturally occurring polyphenolic substances with antioxidative and anti-inflammatory actions in various disease states [124]. They may also have antiviral properties and several representatives of this family, such as quercetin, have been proposed as a potential treatment of COVID-19 [125,126]. Luteolin from Veronica linariifolia may also be beneficial, since it has been shown to prevent viral entry into the host cell by inhibiting the binding of the SARS-CoV spike protein [127]. A potential antiviral activity via the inhibition of the SARS-CoV helicase has been reported for luteolin, myricetin (from Myricanagi), and scutellarin (from Scutellaria barbata) [128]. Finally, the antiviral activity of kaempferol has been suggested to derive from the inhibition of the 3a-channel protein of SARS-CoV [129].

Several flavonoids inhibit in vitro the expression and/or release of mediators, such as histamine, by human and rodent mast cells [130-132]. More specifically, quercetin inhibits mast cell activation and release of histamine and may modulate airway inflammation $[133,134]$. Likewise, luteolin or a structural analog of luteolin inhibit mast cell activation and histamine release from animal and human mast cells [135-137]. The modulatory action of flavonoids on mast cell secretory function affects both IgE-dependent and independent processes and appears to be selective [130]. Some flavonoids, such as caffeic acid, inhibit selective histamine release, while others, such as luteolin and myricetin, inhibit both histamine and $\beta$-hexosaminidase release [138]. This inhibitory action may involve the suppression of NF-kB activation $[137,139]$. The inhibition of calcium influx and protein kinase $C$ translocation and activity mediate the actions of luteolin and quercetin on histamine release from murine bone marrow-derived mast cells, rat peritoneal mast cells, and human cultured cord blood-derived mast cells [131,140,141]. Similarly, quercetin, kaempferol, and myricetin suppressed IgE-mediated activation and histamine release from human umbilical cord blood-derived cultured mast cells. The proposed mechanism includes the decrease of intracellular calcium influx and the inhibition of protein kinase Ctheta isoenzyme signaling [140]. Finally, luteolin inhibits neuropeptide (non-IgE mediated) stimulation of mast cells via the mammalian target of rapamycin (mTOR) signaling [142].

\subsection{Curcumin}

Curcumin is a natural yellow constituent of turmeric or curry powder that is derived from the rhizome of Curcuma longa plants [143]. Curcumin has been reported as a pleiotropic molecule with various biological actions including antioxidant and antiinflammatory effects [144]. The oral or intranasal administration of curcumin has been shown to suppress airway inflammation and remodeling and to inhibit airway hyperreactivity to histamine and bronchoconstriction in animal models of asthma $[145,146]$. Curcumin may also exhibit antiviral activities and has been shown to hamper the replication and proliferation of SARS-CoV-1, the first beta-coronavirus that caused the 2003 SARS outbreak and shares a substantial genetic similarity with SARS-CoV-2 [147]. Moreover, in a rat experimental model, curcumin administration resulted in the attenuation of myocardial fibrosis by modulating angiotensin receptors and ACE2 [4,148]. A similar role could be proposed in the fibrotic process that emerges as a secondary event in severe COVID-19 [148]. Along with its well-known anti-inflammatory effects, curcumin has been reported to inhibit mast cell degranulation and histamine release in vitro and in vivo [149-151]. A possible mechanism may include the in vivo suppression of the Syk-dependent phosphorylations, which are critical for mast cell activation. Although the phosphorylation of Syk itself was not affected, curcumin directly inhibited Syk kinase activity in vitro [149]. Curcumin also inhibited the phosphorylation of additional down-stream signaling molecules including Akt, p38, and JNK [149]. 


\section{Conclusions}

There is an ongoing need for new therapeutic modalities against SARS-CoV-2 infection that continues to spread rapidly around the world. Mounting evidence shows that hyper-inflammation is the hallmark of COVID-19 pathophysiology leading to significant morbidity and mortality. The majority of the histamine secreted by mast cells may play an important role in the pathophysiology of COVID-19 and is regarded as a promising pharmacological target. The activation of pulmonary mast cells releases mediators with proinflammatory, fibrotic, and thrombogenic properties. Moreover, observational studies have shown the potential benefits of $\mathrm{H} 2$ receptor antagonists in patients with COVID-19. However, given the relative paucity of agents targeting mast cells, it may be rational to consider alternative treatments with pleiotropic properties including the modulation of histamine release. Mast cell-derived histamine can regulate not only adaptive and immune system responses but also vasodilatation by binding to endothelial $\mathrm{H} 1$ receptors and enhancing NO production. In an inverse way, histamine-induced NO can negatively modulate mast cell activation, mediator expression, and secretion, thus creating an autocrine loop [152]. In this context, several in vivo and in vitro studies indicate that mast cell activity can be regulated by various nutraceuticals that have gained interest for the treatment of COVID-19. In this way, immunonutrition could lead to a reduction in the de novo synthesis and/or release of histamine and other mast cell mediators that are considered to mediate, at least in part, the immune and microvascular alterations present in COVID-19 (Figure 1). These regimens could be used prophylactically or adjunctively to the conventional treatment of patients infected with SARS-CoV-2. We should point out that for other nutrients, such as glutamine and arginine that have been extensively studied for their immune modifying effect, there are no data available regarding their role on mast cells and histamine during SARS-CoV-2 infection. Nevertheless, the clinical evidence is still limited, and further investigations are necessary to validate the efficacy of nutraceuticals in managing the immune response in COVID-19, and, in particular, modulating mast cell activity.

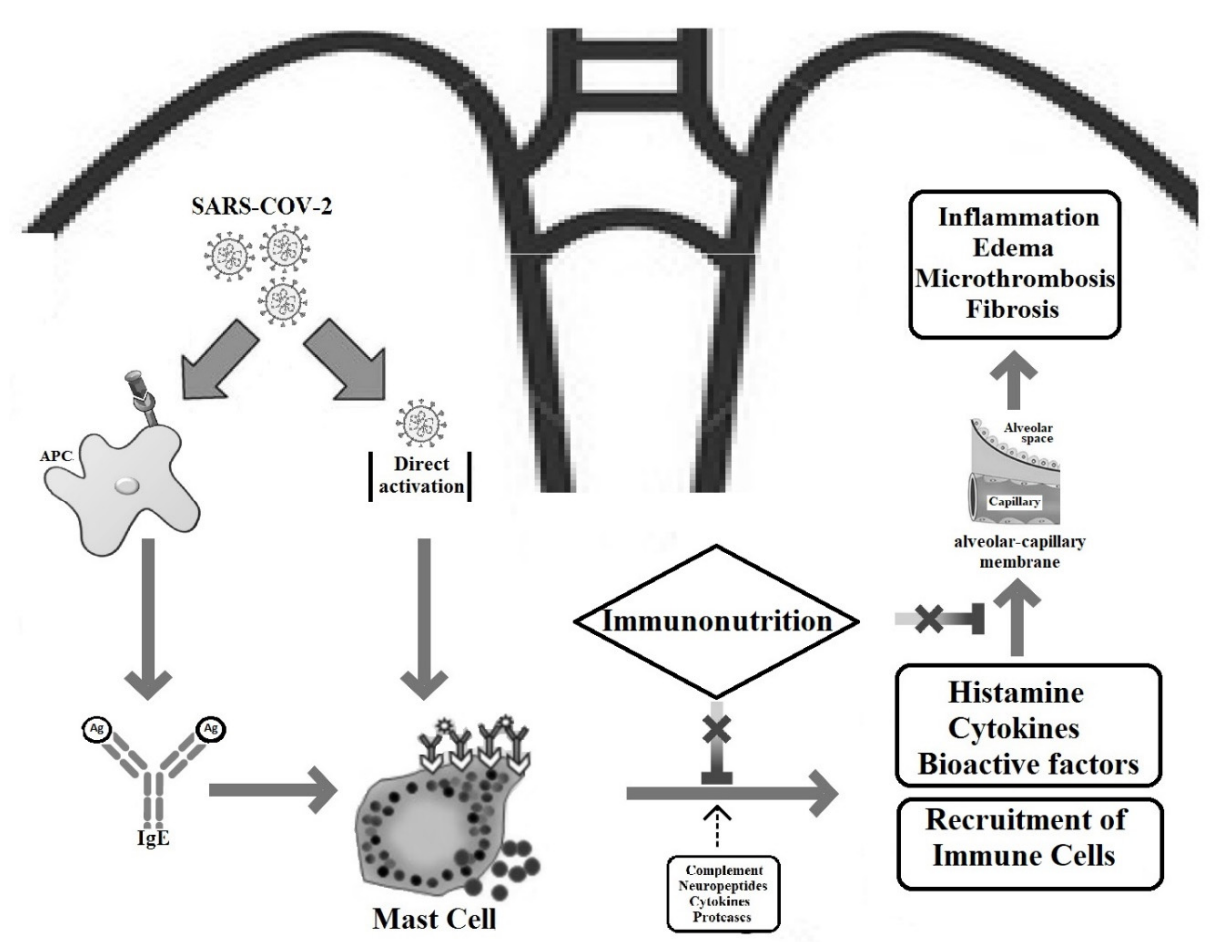

Figure 1. Schematic representation of the modulatory activity of immunonutrients with potential use in COVID-19 on mast cells and histamine during SARS-CoV-2 infection. APC: antigen-producing cells (macrophages or dendritic cells). 
Author Contributions: D.K. and S.K. contributed equally to this work. S.K. drafted the manuscript and D.K. and Z.M. revised it. All authors have read and agreed to the published version of the manuscript.

Funding: This research received no external funding.

Institutional Review Board Statement: Not applicable.

Informed Consent Statement: Not applicable.

Data Availability Statement: Not applicable.

Conflicts of Interest: The authors declare no conflict of interest.

\author{
Abbreviations \\ SARS-CoV-2 severe acute respiratory syndrome coronavirus 2 \\ COVID-19 coronavirus disease 2019 \\ ACE2 angiotensin-converting enzyme 2 \\ ARDS acute respiratory distress syndrome
}

\title{
References
}

1. Poon, L.L.M.; Peiris, M. Emergence of a novel human coronavirus threatening human health. Nat. Med. 2020, 26, 317-319. [CrossRef] [PubMed]

2. Naqvi, A.A.T.; Fatima, K.; Mohammad, T.; Fatima, U.; Singh, I.K.; Singh, A.; Atif, S.M.; Hariprasad, G.; Hasan, G.M.; Hassan, M.I. Insights into SARS-CoV-2 genome, structure, evolution, pathogenesis and therapies: Structural genomics approach. Biochim. Biophys. Acta Mol. Basis Dis. 2020, 1866, 165878. [CrossRef]

3. Tai, W.; He, L.; Zhang, X.; Pu, J.; Voronin, D.; Jiang, S.; Zhou, Y.; Du, L. Characterization of the receptor-binding domain (RBD) of 2019 novel coronavirus: Implication for development of RBD protein as a viral attachment inhibitor and vaccine. Cell. Mol. Immunol. 2020, 17, 613-620. [CrossRef] [PubMed]

4. Liu, Z.; Xiao, X.; Wei, X.; Li, J.; Yang, J.; Tan, H.; Zhu, J.; Zhang, Q.; Wu, J.; Liu, L. Composition and divergence of coronavirus spike proteins and host ACE2 receptors predict potential intermediate hosts of SARS-CoV-2. J. Med. Virol. 2020, 92, 595-601. [CrossRef] [PubMed]

5. Chen, G.; Wu, D.; Guo, W.; Cao, Y.; Huang, D.; Wang, H.; Wang, T.; Zhang, X.; Chen, H.; Yu, H.; et al. Clinical and immunological features of severe and moderate coronavirus disease 2019. J. Clin. Investig. 2020, 130, 2620-2629. [CrossRef] [PubMed]

6. Huang, C.; Wang, Y.; Li, X.; Ren, L.; Zhao, J.; Hu, Y.; Zhang, L.; Fan, G.; Xu, J.; Gu, X.; et al. Clinical features of patients infected with 2019 novel coronavirus in Wuhan, China. Lancet 2020, 395, 497-506. [CrossRef]

7. Peddapalli, A.; Gehani, M.; Kalle, A.M.; Peddapalli, S.R.; Peter, A.E.; Sharad, S. Demystifying Excess Immune Response in COVID-19 to Reposition an Orphan Drug for Down-Regulation of NF-kB: A Systematic Review. Viruses 2021, 13, 378. [CrossRef]

8. Ye, Q.; Wang, B.; Mao, J. The pathogenesis and treatment of the 'Cytokine Storm' in COVID-19. J. Infect. 2020, 80, 607-613. [CrossRef]

9. Tete, S.; Tripodi, D.; Rosati, M.; Conti, F.; Maccauro, G.; Saggini, A.; Salini, V.; Cianchetti, E.; Caraffa, A.; Antinolfi, P.; et al. Role of mast cells in innate and adaptive immunity. J. Biol. Regul. Homeost. Agents 2012, 26, 193-201.

10. McFadyen, J.D.; Stevens, H.; Peter, K. The Emerging Threat of (Micro)Thrombosis in COVID-19 and Its Therapeutic Implications. Circ. Res. 2020, 127, 571-587. [CrossRef]

11. Ackermann, M.; Verleden, S.E.; Kuehnel, M.; Haverich, A.; Welte, T.; Laenger, F.; Vanstapel, A.; Werlein, C.; Stark, H.; Tzankov, A.; et al. Pulmonary Vascular Endothelialitis, Thrombosis, and Angiogenesis in Covid-19. N. Engl. J. Med. 2020, 383, 120-128. [CrossRef]

12. Thangam, E.B.; Jemima, E.A.; Singh, H.; Baig, M.S.; Khan, M.; Mathias, C.B.; Church, M.K.; Saluja, R. The Role of Histamine and Histamine Receptors in Mast Cell-Mediated Allergy and Inflammation: The Hunt for New Therapeutic Targets. Front. Immunol. 2018, 9, 1873. [CrossRef]

13. Yu, Y.; Blokhuis, B.R.; Garssen, J.; Redegeld, F.A. Non-IgE mediated mast cell activation. Eur. J. Pharmacol. 2016, 778, 33-43. [CrossRef]

14. Marshall, J.S.; Portales-Cervantes, L.; Leong, E. Mast Cell Responses to Viruses and Pathogen Products. Int. J. Mol. Sci. 2019, 20, 4241. [CrossRef]

15. Thurmond, R.L.; Gelfand, E.W.; Dunford, P.J. The role of histamine H1 and H4 receptors in allergic inflammation: The search for new antihistamines. Nat. Rev. Drug Discov. 2008, 7, 41-53. [CrossRef] [PubMed]

16. Pal, S.; Gasheva, O.Y.; Zawieja, D.C.; Meininger, C.J.; Gashev, A.A. Histamine-mediated autocrine signaling in mesenteric perilymphatic mast cells. Am. J. Physiol. Regul. Integr. Comp. Physiol. 2020, 318, R590-R604. [CrossRef] [PubMed]

17. Movat, H.Z. The role of histamine and other mediators in microvascular changes in acute inflammation. Can. J. Physiol. Pharmacol. 1987, 65, 451-457. [CrossRef] 
18. Jutel, M.; Watanabe, T.; Klunker, S.; Akdis, M.; Thomet, O.A.; Malolepszy, J.; Zak-Nejmark, T.; Koga, R.; Kobayashi, T.; Blaser, K.; et al. Histamine regulates T-cell and antibody responses by differential expression of $\mathrm{H} 1$ and $\mathrm{H} 2$ receptors. Nature 2001, 413, 420-425. [CrossRef]

19. Branco, A.; Yoshikawa, F.S.Y.; Pietrobon, A.J.; Sato, M.N. Role of Histamine in Modulating the Immune Response and Inflammation. Mediat. Inflamm. 2018, 2018, 9524075. [CrossRef] [PubMed]

20. Theoharides, T.C. COVID-19, pulmonary mast cells, cytokine storms, and beneficial actions of luteolin. Biofactors 2020, 46, 306-308. [CrossRef]

21. Theoharides, T.C. Potential association of mast cells with coronavirus disease 2019. Ann. Allergy Asthma Immunol. 2021, 126, 217-218. [CrossRef]

22. Ennis, M.; Tiligada, K. Histamine receptors and COVID-19. Inflamm. Res. 2021, 70, 67-75. [CrossRef]

23. Tan, J.A.D.; Rathore, A.P.S.; O’Neill, A.; Mantri, C.K.; Saron, W.A.A.; Lee, C.; Cui, C.W.; Kang, A.E.Z.; Foo, R.; Kalimuddin, S.; et al. Signatures of mast cell activation are associated with severe COVID-19. medRxiv 2021. [CrossRef]

24. Carlos, D.; Sá-Nunes, A.; de Paula, L.; Matias-Peres, C.; Jamur, M.C.; Oliver, C.; Serra, M.F.; Martins, M.A.; Faccioli, L.H. Histamine modulates mast cell degranulation through an indirect mechanism in a model IgE-mediated reaction. Eur. J. Immunol. 2006, 36, 1494-1503. [CrossRef]

25. Conti, P.; Caraffa, A.; Tetè, G.; Gallenga, C.E.; Ross, R.; Kritas, S.K.; Frydas, I.; Younes, A.; di Emidio, P.; Ronconi, G. Mast cells activated by SARS-CoV-2 release histamine which increases IL-1 levels causing cytokine storm and inflammatory reaction in COVID-19. J. Biol. Regul. Homeost. Agents 2020, 34, 1629-1632. [CrossRef]

26. Abdel Latif, M.; Abdul-Hamid, M.; Galaly, S.R. Effect of diethylcarbamazine citrate and omega-3 fatty acids on trimellitic anhydride-induced rat skin allergy. Asian Pac. J. Allergy Immunol. 2015, 33, 33-41. [CrossRef]

27. Motta Junior, J.D.S.; Miggiolaro, A.; Nagashima, S.; de Paula, C.B.V.; Baena, C.P.; Scharfstein, J.; de Noronha, L. Mast Cells in Alveolar Septa of COVID-19 Patients: A Pathogenic Pathway That May Link Interstitial Edema to Immunothrombosis. Front. Immunol. 2020, 11, 574862. [CrossRef]

28. Vila-Córcoles, A.; Ochoa-Gondar, O.; Satué-Gracia, E.M.; Torrente-Fraga, C.; Gomez-Bertomeu, F.; Vila-Rovira, A.; Hospital-Guardiola, I.; de Diego-Cabanes, C.; Bejarano-Romero, F.; Basora-Gallisà, J. Influence of prior comorbidities and chronic medications use on the risk of COVID-19 in adults: A population-based cohort study in Tarragona, Spain. BMJ Open 2020, 10, e041577. [CrossRef] [PubMed]

29. Qu, C.; Fuhler, G.M.; Pan, Y. Could Histamine H1 Receptor Antagonists Be Used for Treating COVID-19? Int. J. Mol. Sci. 2021, 22, 5672. [CrossRef] [PubMed]

30. Hogan Ii, R.B.; Hogan Iii, R.B.; Cannon, T.; Rappai, M.; Studdard, J.; Paul, D.; Dooley, T.P. Dual-histamine receptor blockade with cetirizine-Famotidine reduces pulmonary symptoms in COVID-19 patients. Pulm. Pharmacol. Ther. 2020, 63, 101942. [CrossRef] [PubMed]

31. Subedi, L.; Tchen, S.; Gaire, B.P.; Hu, B.; Hu, K. Adjunctive Nutraceutical Therapies for COVID-19. Int. J. Mol. Sci. 2021, $22,1963$. [CrossRef]

32. Story, M.J. Essential sufficiency of zinc, $\omega-3$ polyunsaturated fatty acids, vitamin D and magnesium for prevention and treatment of COVID-19, diabetes, cardiovascular diseases, lung diseases and cancer. Biochimie 2021, 187, 94-109. [CrossRef] [PubMed]

33. Shakoor, H.; Feehan, J.; Al Dhaheri, A.S.; Ali, H.I.; Platat, C.; Ismail, L.C.; Apostolopoulos, V.; Stojanovska, L. Immune-boosting role of vitamins D, C, E, zinc, selenium and omega-3 fatty acids: Could they help against COVID-19? Maturitas 2021, 143, 1-9. [CrossRef] [PubMed]

34. Hamulka, J.; Jeruszka-Bielak, M.; Górnicka, M.; Drywień, M.E.; Zielinska-Pukos, M.A. Dietary Supplements during COVID-19 Outbreak. Results of Google Trends Analysis Supported by PLifeCOVID-19 Online Studies. Nutrients 2020, 13, 54. [CrossRef] [PubMed]

35. Minnelli, N.; Gibbs, L.; Larrivee, J.; Sahu, K.K. Challenges of Maintaining Optimal Nutrition Status in COVID-19 Patients in Intensive Care Settings. JPEN J. Parenter. Enter. Nutr. 2020, 44, 1439-1446. [CrossRef]

36. Derbyshire, E.; Delange, J. COVID-19: Is there a role for immunonutrition, particularly in the over 65s? BMJ Nutr. Prev. Health 2020, 3, 100-105. [CrossRef]

37. Jovic, T.H.; Ali, S.R.; Ibrahim, N.; Jessop, Z.M.; Tarassoli, S.P.; Dobbs, T.D.; Holford, P.; Thornton, C.A.; Whitaker, I.S. Could Vitamins Help in the Fight Against COVID-19? Nutrients 2020, 12, 2550. [CrossRef]

38. Grimble, R.F. Basics in clinical nutrition: Immunonutrition-Nutrients which influence immunity: Effect and mechanism of action. Eur. E-J. Clin. Nutr. Metab. 2009, 4, e10-e13. [CrossRef]

39. Bae, M.; Kim, H. Mini-Review on the Roles of Vitamin C, Vitamin D, and Selenium in the Immune System against COVID-19. Molecules 2020, 25, 5346. [CrossRef]

40. Yazdani, S.C.P. Relationship between Vitamin C, Mast Cells and Inflammation. J. Nutr. Food Sci. 2016, 6, 1-3. [CrossRef]

41. Weng, Z.; Zhang, B.; Asadi, S.; Sismanopoulos, N.; Butcher, A.; Fu, X.; Katsarou-Katsari, A.; Antoniou, C.; Theoharides, T.C. Quercetin is more effective than cromolyn in blocking human mast cell cytokine release and inhibits contact dermatitis and photosensitivity in humans. PLoS ONE 2012, 7, e33805. [CrossRef]

42. Jothimani, D.; Kailasam, E.; Danielraj, S.; Nallathambi, B.; Ramachandran, H.; Sekar, P.; Manoharan, S.; Ramani, V.; Narasimhan, G.; Kaliamoorthy, I.; et al. COVID-19: Poor outcomes in patients with zinc deficiency. Int. J. Infect. Dis. 2020, 100, 343-349. [CrossRef] 
43. Yisak, H.; Ewunetei, A.; Kefale, B.; Mamuye, M.; Teshome, F.; Ambaw, B.; Yideg Yitbarek, G. Effects of Vitamin D on COVID-19 Infection and Prognosis: A Systematic Review. Risk Manag. Healthc. Policy 2021, 14, 31-38. [CrossRef]

44. Mitchell, F. Vitamin-D and COVID-19: Do deficient risk a poorer outcome? Lancet Diabetes Endocrinol. 2020, 8, 570. [CrossRef]

45. Ohaegbulam, K.C.; Swalih, M.; Patel, P.; Smith, M.A.; Perrin, R. Vitamin D Supplementation in COVID-19 Patients: A Clinical Case Series. Am. J. Ther. 2020, 27, e485-e490. [CrossRef] [PubMed]

46. Annweiler, G.; Corvaisier, M.; Gautier, J.; Dubée, V.; Legrand, E.; Sacco, G.; Annweiler, C. Vitamin D Supplementation Associated to Better Survival in Hospitalized Frail Elderly COVID-19 Patients: The GERIA-COVID Quasi-Experimental Study. Nutrients 2020, 12, 3377. [CrossRef]

47. Murai, I.H.; Fernandes, A.L.; Sales, L.P.; Pinto, A.J.; Goessler, K.F.; Duran, C.S.C.; Silva, C.B.R.; Franco, A.S.; Macedo, M.B.; Dalmolin, H.H.H.; et al. Effect of a Single High Dose of Vitamin D3 on Hospital Length of Stay in Patients with Moderate to Severe COVID-19: A Randomized Clinical Trial. JAMA 2021, 325, 1053-1060. [CrossRef] [PubMed]

48. Cereda, E.; Bogliolo, L.; Lobascio, F.; Barichella, M.; Zecchinelli, A.L.; Pezzoli, G.; Caccialanza, R. Vitamin D supplementation and outcomes in coronavirus disease 2019 (COVID-19) patients from the outbreak area of Lombardy, Italy. Nutrition 2021, 82, 111055. [CrossRef]

49. Maghbooli, Z.; Sahraian, M.A.; Ebrahimi, M.; Pazoki, M.; Kafan, S.; Tabriz, H.M.; Hadadi, A.; Montazeri, M.; Nasiri, M.; Shirvani, A.; et al. Vitamin D sufficiency, a serum 25-hydroxyvitamin D at least $30 \mathrm{ng} / \mathrm{mL}$ reduced risk for adverse clinical outcomes in patients with COVID-19 infection. PLoS ONE 2020, 15, e0239799. [CrossRef]

50. ClinicalTrials. Available online: https:/ / clinicaltrials.gov/ct2/home (accessed on 27 June 2021).

51. Liu, Z.Q.; Li, X.X.; Qiu, S.Q.; Yu, Y.; Li, M.G.; Yang, L.T.; Li, L.J.; Wang, S.; Zheng, P.Y.; Liu, Z.G.; et al. Vitamin D contributes to mast cell stabilization. Allergy 2017, 72, 1184-1192. [CrossRef]

52. Yip, K.H.; Kolesnikoff, N.; Yu, C.; Hauschild, N.; Taing, H.; Biggs, L.; Goltzman, D.; Gregory, P.A.; Anderson, P.H.; Samuel, M.S.; et al. 3 metabolite repression of IgE-dependent mast cell activation. J. Allergy Clin. Immunol. 2014, 133, 1356-1364. [CrossRef]

53. Lin, S.; Cicala, C.; Scharenberg, A.M.; Kinet, J.P. The Fc(epsilon)RIbeta subunit functions as an amplifier of Fc(epsilon)RIgammamediated cell activation signals. Cell 1996, 85, 985-995. [CrossRef]

54. Ban, T.; Sato, G.R.; Nishiyama, A.; Akiyama, A.; Takasuna, M.; Umehara, M.; Suzuki, S.; Ichino, M.; Matsunaga, S.; Kimura, A.; et al. Lyn Kinase Suppresses the Transcriptional Activity of IRF5 in the TLR-MyD88 Pathway to Restrain the Development of Autoimmunity. Immunity 2016, 45, 319-332. [CrossRef]

55. Amir-Moazami, O.; Alexia, C.; Charles, N.; Launay, P.; Monteiro, R.C.; Benhamou, M. Phospholipid scramblase 1 modulates a selected set of IgE receptor-mediated mast cell responses through LAT-dependent pathway. J. Biol. Chem. 2008, 283, 25514-25523. [CrossRef]

56. Luciani, F.; Caroleo, M.C.; Cannataro, R.; Mirra, D.; D'Agostino, B.; Gallelli, L.; Cione, E. Immunological Response to SARS-CoV-2 Is Sustained by Vitamin D: A Case Presentation of One-Year Follow-Up. Reports 2021, 4, 18. [CrossRef]

57. Tanaka, J.; Fujiwara, H.; Torisu, M. Vitamin E and immune response. I. Enhancement of helper T cell activity by dietary supplementation of vitamin E in mice. Immunology 1979, 38, 727-734. [PubMed]

58. Lewis, E.D.; Meydani, S.N.; Wu, D. Regulatory role of vitamin E in the immune system and inflammation. IUBMB Life 2019, 71, 487-494. [CrossRef] [PubMed]

59. Lee, G.Y.; Han, S.N. The Role of Vitamin E in Immunity. Nutrients 2018, 10, 1614. [CrossRef] [PubMed]

60. Beigmohammadi, M.T.; Bitarafan, S.; Hoseindokht, A.; Abdollahi, A.; Amoozadeh, L.; Mahmoodi Ali Abadi, M.; Foroumandi, M. Impact of vitamins A, B, C, D, and E supplementation on improvement and mortality rate in ICU patients with coronavirus-19: A structured summary of a study protocol for a randomized controlled trial. Trials 2020, 21, 614. [CrossRef]

61. Zingg, J.M. Vitamin E and mast cells. Vitam. Horm. 2007, 76, 393-418. [CrossRef]

62. Gueck, T.; Aschenbach, J.R.; Fuhrmann, H. Influence of vitamin E on mast cell mediator release. Vet. Dermatol. 2002, 13, 301-305. [CrossRef] [PubMed]

63. Ranadive, N.S.; Lewis, R. Differential effects of antioxidants and indomethacin on compound 48/80 induced histamine release and $\mathrm{Ca}^{2+}$ uptake in rat mast cells. Immunol. Lett. 1982, 5, 145-150. [CrossRef]

64. Zhao, W.; Gan, X.; Su, G.; Wanling, G.; Li, S.; Hei, Z.; Yang, C.; Wang, H. The interaction between oxidative stress and mast cell activation plays a role in acute lung injuries induced by intestinal ischemia-reperfusion. J. Surg. Res. 2014, 187, 542-552. [CrossRef]

65. Colunga Biancatelli, R.M.L.; Berrill, M.; Marik, P.E. The antiviral properties of vitamin C. Expert Rev. Anti Infect. Ther. 2020, 18, 99-101. [CrossRef] [PubMed]

66. Mandl, J.; Szarka, A.; Bánhegyi, G. Vitamin C: Update on physiology and pharmacology. Br. J. Pharmacol. 2009, 157, 1097-1110. [CrossRef] [PubMed]

67. Kuhn, S.O.; Meissner, K.; Mayes, L.M.; Bartels, K. Vitamin C in sepsis. Curr. Opin. Anaesthesiol. 2018, 31, 55-60. [CrossRef]

68. Marik, P.E.; Khangoora, V.; Rivera, R.; Hooper, M.H.; Catravas, J. Hydrocortisone, Vitamin C, and Thiamine for the Treatment of Severe Sepsis and Septic Shock: A Retrospective Before-After Study. Chest 2017, 151, 1229-1238. [CrossRef]

69. Fowler, A.A., 3rd; Truwit, J.D.; Hite, R.D.; Morris, P.E.; DeWilde, C.; Priday, A.; Fisher, B.; Thacker, L.R., 2nd; Natarajan, R.; Brophy, D.F.; et al. Effect of Vitamin C Infusion on Organ Failure and Biomarkers of Inflammation and Vascular Injury in Patients with Sepsis and Severe Acute Respiratory Failure: The CITRIS-ALI Randomized Clinical Trial. JAMA 2019, 322, 1261-1270. [CrossRef] 
70. Liu, F.; Zhu, Y.; Zhang, J.; Li, Y.; Peng, Z. Intravenous high-dose vitamin C for the treatment of severe COVID-19: Study protocol for a multicentre randomised controlled trial. BMJ Open 2020, 10, e039519. [CrossRef]

71. Feyaerts, A.F.; Luyten, W. Vitamin C as prophylaxis and adjunctive medical treatment for COVID-19? Nutrition 2020, 79-80, 110948. [CrossRef] [PubMed]

72. Ellulu, M.S.; Rahmat, A.; Patimah, I.; Khaza'ai, H.; Abed, Y. Effect of vitamin C on inflammation and metabolic markers in hypertensive and/or diabetic obese adults: A randomized controlled trial. Drug Des. Devel. Ther. 2015, 9, 3405-3412. [CrossRef]

73. Hemilä, H. Vitamin C and common cold-induced asthma: A systematic review and statistical analysis. Allergy Asthma Clin. Immunol. 2013, 9, 46. [CrossRef]

74. Nandi, B.K.; Subramanian, N.; Majumder, A.K.; Chatterjee, I.B. Effect of ascorbic acid on detoxification of histamine under stress conditions. Biochem. Pharmacol. 1974, 23, 643-647. [CrossRef]

75. Subramanian, N.; Nandi, B.K.; Majumder, A.K.; Chatterjee, I.B. Effect of ascorbic acid on detoxification of histamine in rats and guinea pigs under drug treated conditions. Biochem. Pharmacol. 1974, 23, 637-641. [CrossRef]

76. Johnston, C.S.; Martin, L.J.; Cai, X. Antihistamine effect of supplemental ascorbic acid and neutrophil chemotaxis. J. Am. Coll. Nutr. 1992, 11, 172-176. [CrossRef]

77. Clemetson, C.A. Histamine and ascorbic acid in human blood. J. Nutr. 1980, 110, 662-668. [CrossRef]

78. Johnston, C.S.; Solomon, R.E.; Corte, C. Vitamin C depletion is associated with alterations in blood histamine and plasma free carnitine in adults. J. Am. Coll. Nutr. 1996, 15, 586-591. [CrossRef]

79. Hagel, A.F.; Layritz, C.M.; Hagel, W.H.; Hagel, H.J.; Hagel, E.; Dauth, W.; Kressel, J.; Regnet, T.; Rosenberg, A.; Neurath, M.F.; et al. Intravenous infusion of ascorbic acid decreases serum histamine concentrations in patients with allergic and non-allergic diseases. Naunyn Schmiedebergs Arch. Pharmacol. 2013, 386, 789-793. [CrossRef] [PubMed]

80. Mio, M.; Yabuta, M.; Kamei, C. Ultraviolet B (UVB) light-induced histamine release from rat peritoneal mast cells and its augmentation by certain phenothiazine compounds. Immunopharmacology 1999, 41, 55-63. [CrossRef]

81. Maintz, L.; Novak, N. Histamine and histamine intolerance. Am. J. Clin. Nutr. 2007, 85, 1185-1196. [CrossRef]

82. Ibs, K.H.; Rink, L. Zinc-altered immune function. J. Nutr. 2003, 133, 1452s-1456s. [CrossRef] [PubMed]

83. Skalny, A.V.; Rink, L.; Ajsuvakova, O.P.; Aschner, M.; Gritsenko, V.A.; Alekseenko, S.I.; Svistunov, A.A.; Petrakis, D.; Spandidos, D.A.; Aaseth, J.; et al. Zinc and respiratory tract infections: Perspectives for COVID-19 (Review). Int. J. Mol. Med. 2020, 46, 17-26. [CrossRef] [PubMed]

84. Mayor-Ibarguren, A.; Busca-Arenzana, C.; Robles-Marhuenda, Á. A Hypothesis for the Possible Role of Zinc in the Immunological Pathways Related to COVID-19 Infection. Front. Immunol. 2020, 11, 1736. [CrossRef] [PubMed]

85. Te Velthuis, A.J.; van den Worm, S.H.; Sims, A.C.; Baric, R.S.; Snijder, E.J.; van Hemert, M.J. Zn $\left({ }^{2+}\right)$ inhibits coronavirus and arterivirus RNA polymerase activity in vitro and zinc ionophores block the replication of these viruses in cell culture. PLoS Pathog. 2010, 6, e1001176. [CrossRef] [PubMed]

86. Wessels, I.; Rolles, B.; Rink, L. The Potential Impact of Zinc Supplementation on COVID-19 Pathogenesis. Front. Immunol. 2020, 11, 1712. [CrossRef] [PubMed]

87. Zhang, J.; Taylor, E.W.; Bennett, K.; Saad, R.; Rayman, M.P. Association between regional selenium status and reported outcome of COVID-19 cases in China. Am. J. Clin. Nutr. 2020, 111, 1297-1299. [CrossRef] [PubMed]

88. Finzi, E. Treatment of SARS-CoV-2 with high dose oral zinc salts: A report on four patients. Int. J. Infect. Dis. 2020, 99, 307-309. [CrossRef]

89. Carlucci, P.M.; Ahuja, T.; Petrilli, C.; Rajagopalan, H.; Jones, S.; Rahimian, J. Zinc sulfate in combination with a zinc ionophore may improve outcomes in hospitalized COVID-19 patients. J. Med. Microbiol. 2020, 69, 1228-1234. [CrossRef]

90. Nishida, K.; Uchida, R. Role of Zinc Signaling in the Regulation of Mast Cell-, Basophil-, and T Cell-Mediated Allergic Responses. J. Immunol. Res. 2018, 2018, 5749120. [CrossRef]

91. Haase, H.; Rink, L. Zinc signals and immune function. Biofactors 2014, 40, 27-40. [CrossRef]

92. Marone, G.; Columbo, M.; de Paulis, A.; Cirillo, R.; Giugliano, R.; Condorelli, M. Physiological concentrations of zinc inhibit the release of histamine from human basophils and lung mast cells. Agents Actions 1986, 18, 103-106. [CrossRef]

93. Kabu, K.; Yamasaki, S.; Kamimura, D.; Ito, Y.; Hasegawa, A.; Sato, E.; Kitamura, H.; Nishida, K.; Hirano, T. Zinc is required for Fc epsilon RI-mediated mast cell activation. J. Immunol. 2006, 177, 1296-1305. [CrossRef]

94. Jarosz, M.; Olbert, M.; Wyszogrodzka, G.; Młyniec, K.; Librowski, T. Antioxidant and anti-inflammatory effects of zinc. Zincdependent NF-kB signaling. Inflammopharmacology 2017, 25, 11-24. [CrossRef] [PubMed]

95. Nizamutdinova, I.T.; Dusio, G.F.; Gasheva, O.Y.; Skoog, H.; Tobin, R.; Peddaboina, C.; Meininger, C.J.; Zawieja, D.C.; Newell-Rogers, M.K.; Gashev, A.A. Mast cells and histamine are triggering the NF- $\mathrm{B}$-mediated reactions of adult and aged perilymphatic mesenteric tissues to acute inflammation. Aging 2016, 8, 3065-3090. [CrossRef]

96. Harthill, M. Review: Micronutrient selenium deficiency influences evolution of some viral infectious diseases. Biol. Trace Elem. Res. 2011, 143, 1325-1336. [CrossRef]

97. Avery, J.C.; Hoffmann, P.R. Selenium, Selenoproteins, and Immunity. Nutrients 2018, 10, 1203. [CrossRef] [PubMed]

98. Fakhrolmobasheri, M.; Nasr-Esfahany, Z.; Khanahmad, H.; Zeinalian, M. Selenium supplementation can relieve the clinical complications of COVID-19 and other similar viral infections. Int. J. Vitam. Nutr. Res. 2021, 91, 197-199. [CrossRef] [PubMed]

99. Kieliszek, M.; Lipinski, B. Selenium supplementation in the prevention of coronavirus infections (COVID-19). Med. Hypotheses 2020, 143, 109878. [CrossRef] 
100. Seale, L.A.; Torres, D.J.; Berry, M.J.; Pitts, M.W. A role for selenium-dependent GPX1 in SARS-CoV-2 virulence. Am. J. Clin. Nutr. 2020, 112, 447-448. [CrossRef]

101. Brooks, A.C.; Whelan, C.J.; Purcell, W.M. Reactive oxygen species generation and histamine release by activated mast cells: Modulation by nitric oxide synthase inhibition. Br. J. Pharmacol. 1999, 128, 585-590. [CrossRef]

102. Safaralizadeh, R.; Nourizadeh, M.; Zare, A.; Kardar, G.A.; Pourpak, Z. Influence of selenium on mast cell mediator release. Biol. Trace Elem. Res. 2013, 154, 299-303. [CrossRef]

103. Wintergerst, E.S.; Maggini, S.; Hornig, D.H. Contribution of selected vitamins and trace elements to immune function. Ann. Nutr. Metab. 2007, 51, 301-323. [CrossRef] [PubMed]

104. Fenghua Qian, S.M.K.S.P. Selenium and selenoproteins in prostanoid metabolism and immunity. Crit. Rev. Biochem. Mol. Biol. 2019, 54, 484-516. [CrossRef] [PubMed]

105. Hathaway, D.; Pandav, K.; Patel, M.; Riva-Moscoso, A.; Singh, B.M.; Patel, A.; Min, Z.C.; Singh-Makkar, S.; Sana, M.K.; Sanchez-Dopazo, R.; et al. Omega 3 Fatty Acids and COVID-19: A Comprehensive Review. Infect. Chemother. 2020, 52, 478-495. [CrossRef] [PubMed]

106. Das, U.N. Can Bioactive Lipids Inactivate Coronavirus (COVID-19)? Arch. Med. Res. 2020, 51, 282-286. [CrossRef] [PubMed]

107. Weill, P.; Plissonneau, C.; Legrand, P.; Rioux, V.; Thibault, R. May omega-3 fatty acid dietary supplementation help reduce severe complications in Covid-19 patients? Biochimie 2020, 179, 275-280. [CrossRef]

108. Goc, A.; Niedzwiecki, A.; Rath, M. Polyunsaturated $\omega-3$ fatty acids inhibit ACE2-controlled SARS-CoV-2 binding and cellular entry. Sci. Rep. 2021, 11, 5207. [CrossRef] [PubMed]

109. Chen, H.; Wang, S.; Zhao, Y.; Luo, Y.; Tong, H.; Su, L. Correlation analysis of omega-3 fatty acids and mortality of sepsis and sepsis-induced ARDS in adults: Data from previous randomized controlled trials. Nutr. J. 2018, 17, 57. [CrossRef]

110. Langlois, P.L.; D'Aragon, F.; Hardy, G.; Manzanares, W. Omega-3 polyunsaturated fatty acids in critically ill patients with acute respiratory distress syndrome: A systematic review and meta-analysis. Nutrition 2019, 61, 84-92. [CrossRef]

111. Doaei, S.; Gholami, S.; Rastgoo, S.; Gholamalizadeh, M.; Bourbour, F.; Bagheri, S.E.; Samipoor, F.; Akbari, M.E.; Shadnoush, M.; Ghorat, F.; et al. The effect of omega-3 fatty acid supplementation on clinical and biochemical parameters of critically ill patients with COVID-19: A randomized clinical trial. J. Transl. Med. 2021, 19, 128. [CrossRef]

112. Schumann, J.; Basiouni, S.; Gück, T.; Fuhrmann, H. Treating canine atopic dermatitis with unsaturated fatty acids: The role of mast cells and potential mechanisms of action. J. Anim. Physiol. Anim. Nutr. (Berl.) 2014, 98, 1013-1020. [CrossRef]

113. Gueck, T.; Seidel, A.; Baumann, D.; Meister, A.; Fuhrmann, H. Alterations of mast cell mediator production and release by gamma-linolenic and docosahexaenoic acid. Vet. Dermatol. 2004, 15, 309-314. [CrossRef] [PubMed]

114. Wang, X.; Ma, D.W.; Kang, J.X.; Kulka, M. n-3 Polyunsaturated fatty acids inhibit Fc $\varepsilon$ receptor I-mediated mast cell activation. J. Nutr. Biochem. 2015, 26, 1580-1588. [CrossRef] [PubMed]

115. Van den Elsen, L.W.; Nusse, Y.; Balvers, M.; Redegeld, F.A.; Knol, E.F.; Garssen, J.; Willemsen, L.E. n-3 Long-chain PUFA reduce allergy-related mediator release by human mast cells in vitro via inhibition of reactive oxygen species. Br. J. Nutr. 2013, 109, 1821-1831. [CrossRef] [PubMed]

116. Park, B.K.; Park, S.; Park, J.B.; Park, M.C.; Min, T.S.; Jin, M. Omega-3 fatty acids suppress Th2-associated cytokine gene expressions and GATA transcription factors in mast cells. J. Nutr. Biochem. 2013, 24, 868-876. [CrossRef] [PubMed]

117. Jang, H.Y.; Koo, J.H.; Lee, S.M.; Park, B.H. Atopic dermatitis-like skin lesions are suppressed in fat- 1 transgenic mice through the inhibition of inflammasomes. Exp. Mol. Med. 2018, 50,1-9. [CrossRef] [PubMed]

118. Kim, T.H.; Kim, G.D.; Jin, Y.H.; Park, Y.S.; Park, C.S. Omega-3 fatty acid-derived mediator, Resolvin E1, ameliorates 2,4dinitrofluorobenzene-induced atopic dermatitis in NC/Nga mice. Int. Immunopharmacol. 2012, 14, 384-391. [CrossRef] [PubMed]

119. Gueck, T.; Seidel, A.; Fuhrmann, H. Effects of essential fatty acids on mediators of mast cells in culture. Prostaglandins Leukot Essent Fat. Acids 2003, 68, 317-322. [CrossRef]

120. Van Diest, S.A.; van den Elsen, L.W.; Klok, A.J.; Welting, O.; Hilbers, F.W.; van de Heijning, B.J.; Gaemers, I.C.; Boeckxstaens, G.E.; Werner, M.F.; Willemsen, L.E.; et al. Dietary Marine n-3 PUFAs Do Not Affect Stress-Induced Visceral Hypersensitivity in a Rat Maternal Separation Model. J. Nutr. 2015, 145, 915-922. [CrossRef]

121. Willemsen, L.E.M. Dietary n-3 long chain polyunsaturated fatty acids in allergy prevention and asthma treatment. Eur. J. Pharmacol. 2016, 785, 174-186. [CrossRef]

122. Brannan, J.D.; Bood, J.; Alkhabaz, A.; Balgoma, D.; Otis, J.; Delin, I.; Dahlén, B.; Wheelock, C.E.; Nair, P.; Dahlén, S.E.; et al. The effect of omega-3 fatty acids on bronchial hyperresponsiveness, sputum eosinophilia, and mast cell mediators in asthma. Chest 2015, 147, 397-405. [CrossRef]

123. Arm, J.P.; Horton, C.E.; Spur, B.W.; Mencia-Huerta, J.M.; Lee, T.H. The effects of dietary supplementation with fish oil lipids on the airways response to inhaled allergen in bronchial asthma. Am. Rev. Respir. Dis. 1989, 139, 1395-1400. [CrossRef]

124. Cushnie, T.P.; Lamb, A.J. Antimicrobial activity of flavonoids. Int. J. Antimicrob. Agents 2005, 26, 343-356. [CrossRef]

125. Derosa, G.; Maffioli, P.; D'Angelo, A.; di Pierro, F. A role for quercetin in coronavirus disease 2019 (COVID-19). Phytother. Res. 2021, 35, 1230-1236. [CrossRef] [PubMed]

126. Colunga Biancatelli, R.M.L.; Berrill, M.; Catravas, J.D.; Marik, P.E. Quercetin and Vitamin C: An Experimental, Synergistic Therapy for the Prevention and Treatment of SARS-CoV-2 Related Disease (COVID-19). Front. Immunol. 2020, 11, 1451. [CrossRef] [PubMed] 
127. Yi, L.; Li, Z.; Yuan, K.; Qu, X.; Chen, J.; Wang, G.; Zhang, H.; Luo, H.; Zhu, L.; Jiang, P.; et al. Small molecules blocking the entry of severe acute respiratory syndrome coronavirus into host cells. J. Virol. 2004, 78, 11334-11339. [CrossRef] [PubMed]

128. Yu, M.S.; Lee, J.; Lee, J.M.; Kim, Y.; Chin, Y.W.; Jee, J.G.; Keum, Y.S.; Jeong, Y.J. Identification of myricetin and scutellarein as novel chemical inhibitors of the SARS coronavirus helicase, nsP13. Bioorg. Med. Chem. Lett. 2012, 22, 4049-4054. [CrossRef] [PubMed]

129. Wen, C.C.; Shyur, L.F.; Jan, J.T.; Liang, P.H.; Kuo, C.J.; Arulselvan, P.; Wu, J.B.; Kuo, S.C.; Yang, N.S. Traditional Chinese medicine herbal extracts of Cibotium barometz, Gentiana scabra, Dioscorea batatas, Cassia tora, and Taxillus chinensis inhibit SARS-CoV replication. J. Tradit. Complement. Med. 2011, 1, 41-50. [CrossRef]

130. Alexandrakis, M.; Singh, L.; Boucher, W.; Letourneau, R.; Theofilopoulos, P.; Theoharides, T.C. Differential effect of flavonoids on inhibition of secretion and accumulation of secretory granules in rat basophilic leukemia cells. Int. J. Immunopharmacol. 1999, 21, 379-390. [CrossRef]

131. Kimata, M.; Inagaki, N.; Nagai, H. Effects of luteolin and other flavonoids on IgE-mediated allergic reactions. Planta Med. 2000, 66, 25-29. [CrossRef]

132. Yang, Y.; Oh, J.M.; Heo, P.; Shin, J.Y.; Kong, B.; Shin, J.; Lee, J.C.; Oh, J.S.; Park, K.W.; Lee, C.H.; et al. Polyphenols differentially inhibit degranulation of distinct subsets of vesicles in mast cells by specific interaction with granule-type-dependent SNARE complexes. Biochem. J. 2013, 450, 537-546. [CrossRef]

133. Pearce, F.L.; Befus, A.D.; Bienenstock, J. Mucosal mast cells. III. Effect of quercetin and other flavonoids on antigen-induced histamine secretion from rat intestinal mast cells. J. Allergy Clin. Immunol. 1984, 73, 819-823. [CrossRef]

134. Mlcek, J.; Jurikova, T.; Skrovankova, S.; Sochor, J. Quercetin and Its Anti-Allergic Immune Response. Molecules 2016, $21,623$. [CrossRef] [PubMed]

135. Seelinger, G.; Merfort, I.; Schempp, C.M. Anti-oxidant, anti-inflammatory and anti-allergic activities of luteolin. Planta Med. 2008, 74, 1667-1677. [CrossRef] [PubMed]

136. Weng, Z.; Patel, A.B.; Panagiotidou, S.; Theoharides, T.C. The novel flavone tetramethoxyluteolin is a potent inhibitor of human mast cells. J. Allergy Clin. Immunol. 2015, 135, 1044-1052. [CrossRef] [PubMed]

137. Bawazeer, M.A.; Theoharides, T.C. IL-33 stimulates human mast cell release of CCL5 and CCL2 via MAPK and NF-kB, inhibited by methoxyluteolin. Eur. J. Pharmacol. 2019, 865, 172760. [CrossRef]

138. Hagenlocher, Y.; Lorentz, A. Immunomodulation of mast cells by nutrients. Mol. Immunol. 2015, 63, 25-31. [CrossRef] [PubMed]

139. Park, H.H.; Lee, S.; Son, H.Y.; Park, S.B.; Kim, M.S.; Choi, E.J.; Singh, T.S.; Ha, J.H.; Lee, M.G.; Kim, J.E.; et al. Flavonoids inhibit histamine release and expression of proinflammatory cytokines in mast cells. Arch. Pharm. Res. 2008, 31, 1303-1311. [CrossRef]

140. Kempuraj, D.; Madhappan, B.; Christodoulou, S.; Boucher, W.; Cao, J.; Papadopoulou, N.; Cetrulo, C.L.; Theoharides, T.C. Flavonols inhibit proinflammatory mediator release, intracellular calcium ion levels and protein kinase $C$ theta phosphorylation in human mast cells. Br. J. Pharmacol. 2005, 145, 934-944. [CrossRef]

141. Kimata, M.; Shichijo, M.; Miura, T.; Serizawa, I.; Inagaki, N.; Nagai, H. Effects of luteolin, quercetin and baicalein on immunoglobulin E-mediated mediator release from human cultured mast cells. Clin. Exp. Allergy 2000, 30, 501-508. [CrossRef]

142. Patel, A.B.; Theoharides, T.C. Methoxyluteolin Inhibits Neuropeptide-stimulated Proinflammatory Mediator Release via mTOR Activation from Human Mast Cells. J. Pharmacol. Exp. Ther. 2017, 361, 462-471. [CrossRef]

143. Gupta, S.C.; Kismali, G.; Aggarwal, B.B. Curcumin, a component of turmeric: From farm to pharmacy. Biofactors 2013, 39 , 2-13. [CrossRef] [PubMed]

144. Kurup, V.P.; Barrios, C.S. Immunomodulatory effects of curcumin in allergy. Mol. Nutr. Food Res. 2008, 52, 1031-1039. [CrossRef] [PubMed]

145. Ram, A.; Das, M.; Ghosh, B. Curcumin attenuates allergen-induced airway hyperresponsiveness in sensitized guinea pigs. Biol. Pharm. Bull. 2003, 26, 1021-1024. [CrossRef] [PubMed]

146. Chauhan, P.S.; Subhashini; Dash, D.; Singh, R. Intranasal curcumin attenuates airway remodeling in murine model of chronic asthma. Int. Immunopharmacol. 2014, 21, 63-75. [CrossRef]

147. Wen, C.C.; Kuo, Y.H.; Jan, J.T.; Liang, P.H.; Wang, S.Y.; Liu, H.G.; Lee, C.K.; Chang, S.T.; Kuo, C.J.; Lee, S.S.; et al. Specific plant terpenoids and lignoids possess potent antiviral activities against severe acute respiratory syndrome coronavirus. J. Med. Chem. 2007, 50, 4087-4095. [CrossRef]

148. Spagnolo, P.; Balestro, E.; Aliberti, S.; Cocconcelli, E.; Biondini, D.; Casa, G.D.; Sverzellati, N.; Maher, T.M. Pulmonary fibrosis secondary to COVID-19: A call to arms? Lancet Respir. Med. 2020, 8, 750-752. [CrossRef]

149. Lee, J.H.; Kim, J.W.; Ko, N.Y.; Mun, S.H.; Her, E.; Kim, B.K.; Han, J.W.; Lee, H.Y.; Beaven, M.A.; Kim, Y.M.; et al. Curcumin, a constituent of curry, suppresses IgE-mediated allergic response and mast cell activation at the level of Syk. J. Allergy Clin. Immunol. 2008, 121, 1225-1231. [CrossRef]

150. Zhang, N.; Li, H.; Jia, J.; He, M. Anti-inflammatory effect of curcumin on mast cell-mediated allergic responses in ovalbumininduced allergic rhinitis mouse. Cell. Immunol. 2015, 298, 88-95. [CrossRef]

151. Ju, H.R.; Wu, H.Y.; Nishizono, S.; Sakono, M.; Ikeda, I.; Sugano, M.; Imaizumi, K. Effects of dietary fats and curcumin on IgE-mediated degranulation of intestinal mast cells in brown Norway rats. Biosci. Biotechnol. Biochem. 1996, 60, 1856-1860. [CrossRef]

152. Galli, S.J.; Gaudenzio, N.; Tsai, M. Mast Cells in Inflammation and Disease: Recent Progress and Ongoing Concerns. Annu. Rev. Immunol. 2020, 38, 49-77. [CrossRef] [PubMed] 